Agata Jawoszek

Instytut Filologii Słowiańskiej

UAM Poznań

http://dx.doi.org/10.18778/8088-249-2.19

\title{
BOSZNIACKA DIASPORA W EUROPIE ZACHODNIEJ W ŚWIETLE KRYZYSU IMIGRACYJNEGO I ROSNĄCEJ ISLAMOFOBII MEDIA, TOŻSAMOŚĆ I POLITYKA ${ }^{1}$
}

\section{Wprowadzenie}

Podejmując temat boszniackiej czy też, zgodnie z nomenklaturą obowiązującą do 1992 r., bośniacko-muzułmańskiej diaspory w Europie i na innych kontynentach, należy mieć świadomość, jak rozległe jest to zagadnienie oraz jak wiele problemów i pułapek czyha tu na badacza. Przyczyną jest specyfika tej diaspory - niejednorodnej, silnie zróżnicowanej pod względem narodowym, o różnym stopniu więzi z macierzystym krajem, wewnętrznej integracji, asymilacji i tendencji autoidentyfikacyjnych. W przypadku omawianej tu diaspory muzułmanów z Bośni i Hercegowiny, wpływ na taki stan rzeczy miały przede wszystkim etniczna złożoność kraju nad Miljacką oraz historyczne uwarunkowania i przyczyny masowych ruchów migracyjnych z Bośni i Hercegowiny, których dzisiejszy bośniacki krajobraz na obczyźnie jest skutkiem. Inaczej funkcjonuje najstarsza bośniacka diaspora w Turcji i Macedonii, mająca swoje korzenie w ostatnich dziesięcioleciach osmańskiego panowania nad Bałkanami i w pierwszych kilkunastu latach po aneksji Bośni i Hercegowiny przez Austro-Węgry w 1878 r., znana w literaturze przedmiotu pod pojęciem muhadžirluku (wygnaństwa). Inna jest specyfika jugosłowiańsko-bośniackiej diaspory w Słowenii czy Chorwacji, na którą nałożyło się wojenne uchodźstwo z Bośni i Hercegowiny w latach 90. Zupełnie odmienną dynamiką i strukturą cechuje się także zarobkowa emigracja spod znaku gastarbeit w Niemczech czy w Austrii - tu jednak należy pamiętać, że do diaspory złożonej z sezonowych robotników w niemieckojęzycznych krajach Europy Zachodniej w latach 1989-1995 dołączyli uchodźcy z Bośni i Hercego-

1 Artykuł powstał w wyniku realizacji projektu badawczego „Bośniacka diaspora modele narodowej i kulturowej autoidentyfikacji", finansowanego przez Narodowe Centrum Nauki (numer grantu: 2013/08/S/HS2/00449). 
winy. W specyficzny sposób i w swoim niepowtarzalnym rytmie, rozwijała się i kształtowała polityczna emigracja w Szwajcarii po II wojnie światowej, o której bez zbędnej przesady można mówić jako o duchowym boszniackim „rządzie na uchodźstwie”. Mam tu na myśli działalność czołowych ideologów boszniactwa, tj. Adila Zulfikarpašicia i Smaila Balicia, których aktywność i niezliczone publikacje położyły podwalinę pod tzw. II odrodzenie narodowe Boszniaków, najpierw na początku lat 70., a następnie w latach 90. ubiegłego wieku. Jeszcze inna jest specyfika bośniackiej i boszniackiej diaspory w Skandynawii, przede wszystkich w Szwecji i w Norwegii, która ma za sobą najczęściej dramatyczne doświadczenia uchodźstwa przed czystkami etnicznymi, jakich w ostatniej dekadzie ubiegłego wieku dopuszczali się bośniaccy Serbowie. W tej, rozbudowanej, a tu zaledwie wstępnie naszkicowanej, mapie bośniackiej diaspory, specyficzne miejsce zajmuje również serbska prowincja, znana pod historyczną nazwą Sandżak Nowopazarski, traktowana przez boszniackich autorów raz jako „klasyczny przykład diaspory”, innym zaś razem jako dowód transgraniczności boszniackiej tożsamości narodowej [Dervišević 2006: 42]. Przy tak rozległym krajobrazie bośniackiej i boszniackiej diaspory, terminologicznych nieścisłościach, braku rzetelnych danych statystycznych, które prezentowałyby realny obraz i skalę tego zjawiska, trudno jest o ujęcie syntetyzujące. Metodologiczną przeszkodę stanowi tu przede wszystkim rozpatrywanie w tych samych kategoriach bośniackich/boszniackich środowisk emigracyjnych w różnych krajach, ale także „wypreparowanie” diaspory bośniacko-muzułmańskiej z tkanki diaspory bośniackiej, albo szerzej - ex-jugosłowiańskiej czy bałkańskiej.

Najnowsze bośniackie naukowe, popularnonaukowe i prasowe opracowania dotyczące boszniackiej diaspory (Alaga Dervišević, Salih Smajlović) szacują jej liczebność na nawet 10 milionów. Gdyby uznać te dane za rzeczywiste, wówczas liczebność diaspory ponad dwukrotnie przekraczałaby liczebność całej populacji w BiH. Trzeba jednak wyjaśnić, że liczba ta obejmuje bardzo szeroko rozumianą diasporę, Dervišević włącza tu bowiem również Bośniaków mieszkających w Turcji, ich potomków w trzecim, a nawet w czwartym pokoleniu, którzy już niemal całkowicie utracili poczucie bośniakciej/boszniaciej tożsamości i zdolność porozumiewania się w języku dziś nazywanym bośniackim. Warto również zauważyć, że A. Dervišvić jako Boszniaków traktuje także słowiańskojęzycznych muzułmanów z Kosowa, Macedonii, Serbii, a nawet z Bułgarii. Zupełnie innych danych dostarcza Svjetski savez dijaspore Bosne i Hercegovine. W ostatnio opublikowanych danych (II połowa 2014 r.) mówi się o 1,5 milionowej diasporze z Bośni i Hercegowiny w Europie i na innych kontynentach, z której przeważającą większość mieliby stanowić bośniaccy muzułmanie/Boszniacy. Departament ds. Imigracji przy Ministerstwie Bezpieczenstwa $\mathrm{BiH}$ (Ministarstvo sigurnosti Bosne i Hercegovine) podaje za kantonalnym Ministerstwem ds. Praw Człowieka i Uchodźstwa, że poza granicami kraju żyje dziś na stałe ok 1,9 mln Bośniaków i Hercegowców. Liczba ta, poza tym, że obejmuje Boszniaków oraz bośniackich 
Serbów i Chorwatów, uwzględnia również drugie i trzecie pokolenie imigrantów z BiH, osoby, które zrzekły się bośniackiego obywatelstwa lub nigdy o nie nie wystąpily po zakończeniu wojny w 1995 r., osoby o obywatelstwie podwójnym. Nie uwzględnia zaś imigrantów sezonowych oraz osób, które przebywają w krajach przyjmujących nielegalnie lub z fałszywymi dokumentami, ani też osób, które zataiły w spisach ludności swoje pochodzenie (deklarując np. wyłącznie nową przynależność narodową do kraju przyjmującego), co wcale nie musi być zjawiskiem odosobnionym, jeśli wziąć pod uwagę, że - zgodnie z danymi Ministerstwa Spraw Obywatelskich BiH (Ministarstwo za civilne poslove $\mathrm{BiH}$ ) - od 1998 do 2013 r. zostało w kraju złożonych aż 61712 wniosków o zrzeczenie się obywatelstwa. Jedyną sprawdzoną wielkością przytoczoną w raporcie, potwierdzoną przez 15 krajów przyjmujących, jest liczba 1256252 (dane zebrane pomiędzy 2011 a 2013 r.). Zgodnie z raportem, sporządzonym na podstawie danych ze spisów ludności przeprowadzonych w poszczególnych krajach, w Serbii żyje dziś 298835 tysięcy Bośniaków, w Chorwacji 189 039, w Czarnogórze 21 849, zaś w Słowenii 97 142. W Niemczech na stałe zameldowanych jest 155000 Bośniaków, w USA 122 529, w Austrii 116 382, w Szwecji 56 512, w Szwajcarii 49 377, w Kanadzie 39 150, we Włoszech 29 066, w Australii 25 682, w Holandii 25 440, w Danii 17 417, w Norwegii zaś 13232.

Dane te prezentują się dość skromnie, jeśli porównać je z doświadczeniem turysty w większości zachodnioeuropejskich metropolii, w których często słychać język bośniacki/serbski/chorwacki, a bałkańskie restauracje i kawiarnie są nader częstym elementem etnokrajobrazu w imigranckich dzielnicach, przez co można odnieść mylne wrażenie, że co trzeci spotykany Austriak czy Niemiec jest Bośniakiem. Podobnie wyglądają w zestawieniu z liczbami prezentowanymi w mniej umocowanych naukowo publikacjach oraz na portalach internetowych, skupiających środowiska imigrantów z Bośni i Hercegowiny. Dla przykładu, wpisując w popularną wyszukiwarkę internetową frazę: „Ilu Bośniaków mieszka w Niemczech?", otrzymujemy dane wahające się od 120000 do 250 000. Analogiczna rozbieżność dotyczy innych europejskich skupisk diaspory.

\section{1. \# Nie jestem Charlie, jestem Ahmed}

Od przełomu 2014 i 2015 r. temat migracji, uchodźstwa i radykalizacji wyznawców islamu w Europie stał się jednym z kluczowych tematów medialnych i wyzwań, przed, którymi stanęli politycy i społeczeństwa państw Unii Europejskiej. Słowa takie jak uchodźstwo, migracje, zamachy, radykalizm, fanatyzm i fundamentalizm muzułmański oraz Państwo Islamskie, choć niesłusznie zlepiane w jedną, powierzchownie traktowaną zbitkę spod znaku „kryzysu migracyjnego”, stały się elementem europejskiej codzienności i powodem, dla którego marginalizowani, w najlepszym wypadku niezauważani dotąd muzułmańscy imigranci 
z Bośni i Hercegowiny, znaleźli się blisko centrum zainteresowań europejskich mediów. Dramatyczne wydarzenia z 7 stycznia 2015 r. - rozstrzelanie rysowników i dziennikarzy francuskiego czasopisma satyrycznego „Charlie Hebdo” przez tzw. „samotne wilki”, sympatyków i wyznawców Państwa Islamskiego, wywodzących się z francuskich i belgijskich środowisk imigranckich (głównie z krajów Maghrebu), następnie zaś seria brutalnych zamachów w Paryżu i w podparyskiej dzielnicy Saint-Denis w listopadzie tego samego roku, ostatnie zamachy w Brukseli w marcu 2016 r oraz krwawy zamach terrorystyczny w Nicei w dniu święta narodowego Francji, nałożyły się w kształtowanej przez media świadomości społeczeństwa na ogólnoeuropejski kryzys imigracyjny. Warto w tym miejscu przypomnieć, że zamachy w Paryżu i egzekucja autorów „Charlie Hebdo” odbiły się echem także w muzułmańskich społecznościach, również wśród Bośniaków, i to zarówno w kraju, jak i na emigracji. W nowych mediach komunikacyjnych, takich jak Tweeter czy Facebook, dużą popularnością cieszyły się dwie akcje społeczne, mające na celu, $\mathrm{z}$ jednej strony, ocieplenie wizerunku muzułmanów w Europie, z drugiej zaś - zaznaczenie ich obecności, odrębności i trudnej sytuacji, w jakiej się znaleźli w rzeczywistości po zamachach. Mam tu na myśli akcję: „Not in my name”, w ramach której muzułmanie z całego świata umieszczali w mediach społecznościowych zdjęcie z tabliczką głoszącą, że odrażające zbrodnie, których dopuścili się muzułmańscy radykałowie z Państwa Islamskiego zostały popełnione „nie w ich imieniu”. Druga, choć chronologicznie wcześniejsza akcja, była odpowiedzią na hasło, które w tych samych mediach społecznościowych stało się wyrazem solidarności z zamordowanymi dziennikarzami z „Charlie Hebdo”. Podczas gdy internauci lączyli się w bólu z Francuzami, umieszczając na swoich profilach slogan „Je suis Charlie” (Jestem Charlie), wielu muzułmanów utożsamiało się z kimś innym - nie z satyrykami, których rysunki często, $w$ ich odczuciu, szkalowały islam i tak ważną dla muzułmanów postać Proroka, lecz z Ahmedem, policjantem, muzułmaninem, zastrzelonym tego samego dnia przez napastników z „Charlie Hebdo”. Hasło „Je suis Ahmed” stało się symbolem odczuwanej przez muzułmanów ambiwalencji. Z jednej strony, jako Europejczycy, utożsamiają się oni z europejskimi wartościami, z drugiej zaś coraz wyraźniej odczuwają, że stają one w sprzeczności z ich wartościami, kulturą i religią. Znamienne słowa bośniackiego dziennikarza Amira Msrlicia doskonale tę ambiwalencję oddają: Ne, ja nisam Charlie. Koliko god trenutno bilo popularno tvrditi suprotno, ja nisam Charlie. Ja sam Amir. I musliman sam. I novinar sam. I ta moja dva identiteta mi ne dozvoljavaju da šutim. („Nie, ja nie jestem Charlie. Jakkolwiek jest teraz na topie twierdzić co innego, ja nie jestem Charlie. Jestem Amir. I jestem muzulmaninem. I dziennikarzem. Te moje dwie tożsamości nie pozwalają mi milczeć".) [cytat za portalem RadioSarajevo.ba].

Mimo takich oddolnych, społecznych działań ukształtowało się, reprodukowane przez środowiska narodowo-konserwatywne, islamofobiczne przeświadczenie o nieuchronnej „ekspansji radykałów muzułmańskich zalewających Europę" a w skrajnych przypadkach postulaty, by islam zdelegalizować, jako niezgodny 
z polską konstytucją (Miriam Shaded, prezeska Fundacji Estera i sympatyczka Narodowego Odrodzenia Polski, na łamach tygodnika „Wprost”). Jedną z bardziej aktywnych na tym polu inicjatyw społecznych jest spontanicznie powstała grupa oraz będący jego organem medialnym portal „Nie dla islamizacji Europy” (ndie.pl), którego założyciele, przeciwko którym dziś toczy się śledztwo prokuratorskie, tak piszą o sobie: „Nie dla islamizacji Europy” to oddolna obywatelska inicjatywa stworzona dla $i$ wokót idei, która ma łączyć społeczeństwo. Nie zamierzamy popetnić tych samych btędów, co Zachód. Jednoczymy się z myśla o przyszłych pokoleniach, nasz sprzeciw wywodzi się z postaw patriotycznych $i$ tożsamościowych [cytat ze strony internetowej ndie.pl]. Tego typu inicjatyw, demonstracji, wystąpień i grup, zawiązanych w mediach społecznościowych, w ciągu kilku miesięcy było znacznie więcej. Wśród haseł i postulatów noszących znamiona mowy nienawiści, niejednokrotnie nawołujących do przemocy i dyskryminacji na tle rasowym i religijnym, dominowała jedna narracja, w myśl której każdy muzułmański uchodźca czy imigrant to potencjalny terrorysta. $\mathrm{W}$ tym świetle, $\mathrm{w}$ polskich mediach po raz pierwszy zaistnieli również imigranci z Bośni i Hercegowiny, mieszkający w krajach niemieckojęzycznych i w Skandynawii. Jednym z przyczynków do tego wzmożonego zainteresowania Boszniakami był medialnie eksploatowany, w niemal całej Europie, również na Bałkanach, wątek dwóch wiedeńskich nastolatek o bośniackich korzeniach, Samry Kesinović i Sabiny Selimović, które, jeśli wierzyć prasowym doniesieniom, w drugiej połowie 2015 r. uciekły ze swoich domów i przyłączyły się, już jako żony dżihadystów, do bojowników w Syrii. Przypadek Kesinović i Selimović, które najprawdopodobniej zginęły w Damaszku podczas walk lub próby ucieczki, można rozpatrywać na wielu poziomach. Do niezwykle ciekawych wniosków może prowadzić przyjrzenie się z perspektywy genderowej dyskursowi zbudowanemu wokół tragicznych losów tych wiedeńskich nastolatek, a także tendencyjnym zdjęciom, kolażom i fotomontażom, ilustrującym poświęcone im artykuły. Ujawniłby się wówczas klasyczny obraz stereotypowego ujęcia kobiecości i męskości, obciążony dodatkowo kontekstem wyznaniowym, w tym wypadku - muzulmańskim. Przeciwstawienie i skontrastowanie niewinnej dziewczęcości i europejskości Samry i Sabiny, brutalnej seksualności i orientalnej (właściwie orientalizowanej) dzikości syryjskich bojowników zasługuje na osobne rozpracowanie, analizę i omówienie. $\mathrm{Z}$ takiej perspektywy, znaczącymi sygnałami stają się zarówno tak eksponowane na fotografiach i w tekstach prasowych niebieskie oczy i jasne włosy obu dziewcząt (kontekst Boszniaków jako europejskich, a zatem „oswojonych” muzułmanów), jak i przywdziane przez nie już po ucieczce do Syrii burki (będące potwierdzeniem stereotypu o zniewalanej przez „właściwych” muzułmanów kobiecości).

Mają po kilkanaście lat. Niewinne twarze, urocze uśmiechy, w szkole - same piątki. Uciekają z domów, by przyłączyć się do dżihadystów z Państwa Islamskiego czasem walczyć z karabinem w ręku, ale częściej urodzić „świętym męczennikom” 
dzieci. Werbuje się je przez Facebooka, kusząc obietnicami przeżycia prawdziwej przygody. Kim są nastoletnie bojowniczki z Europy, które porzucają kochające rodziny, by walczyć w szeregach IS ?

Podobną funkcję spełniały podawane do publicznej wiadomości, wraz z kolejnymi odsłonami tej dramatycznej historii, informacje o przymusowych ślubach obu nieletnich Austriaczek z bojownikami Państwa Islamskiego oraz o ich rzekomych ciążach. Kobieco-męski aspekt całej tej historii można rozpisać posiłkując się koncepcją dotyczącą strategii i praktyki orientalizacji krajów muzulmańskich i ludzi z nich pochodzących, opisaną przez Edwarda Saida w Orientalizmie. Orientalizacja jest bowiem, jak twierdzi autor fundamentalnego dla teorii postkolonialnej dzieła, „formą paranoi, wiedzą innego rodzaju niż wiedza historyczna” [Said 2005: 120]. Dotąd niepotwierdzone doniesienia, że dziewczęta były bite przez swoich mężów/opiekunów rozpalały wyobraźnię czytelników kolorowej prasy i makabrycznie „rymowały się” z powielanym przez krajowe środowiska prawicowe metaforycznym obrazem Europy (kobiety!), gwałconej bądź napastowanej przez muzułmańskich uchodźców. Doskonałym exemplum takiej personifikacji społecznego napięcia, wywołanego falą uchodźców, jest okładka polskiego konserwatywno-prawicowego tygodnika „W Sieci” z początku 2016 r. Odwołujące się do rasistowskich kodów inscenizowane zdjęcie, przypominające antysemickie plakaty propagandowe z czasów III Rzeszy, przedstawia młodą, jasnowłosą półnagą kobietę, ubraną we flagę Unii Europejskiej, szarpaną przez mężczyzn o wyraźnie ciemniejszej karnacji. Okładka miała stanowić komentarz do sylwestrowych napaści w Kolonii, podczas których ofiarami molestowania seksualnego padło ponad tysiąc kobiet, choć - jak podała niemiecka policja - zaledwie trzech spośród prawie 60 zatrzymanych było uchodźcami z Iraku lub Syrii, to jednak wystarczyło, by wydarzenia, które miały miejsce w nocy z 31 grudnia na 1 stycznia 2016 r. wpisać w islamofobiczną narrację o młodych Arabach zagrażających swoją seksualnością europejskim kobietom, a przez to i europejskiej cywilizacji.

\section{Przypadek Samry i Sabiny}

Zdjęcie rzekomo przedstawiające Samrę lub Sabinę, uzbrojoną i ubraną w zasłaniającą całą twarz burkę, stało się najczęstszą ilustracją artykułów prasowych, poświęconych ich historii. Rober J. C. Young, brytyjski badacz analizujący postkolonialne i postzależnościowe strategie kulturowe, zwraca uwagę, że kobieca zasłona, potocznie i najczęściej błędnie, nazywana burką, hidżabem lub czadorem, jest najbardziej wymownym symbolem odmienności świata zachod-

2 Zob. http://www.tvp.info.pl/17191001/niebieskie-oczy-usmiech-i-karabin-w-reku-kim-sa-nastoletnie-bo-jowniczki-panstwa-islamskiego. 
niego i muzułmańskiego [Young 2012: 97]. Chusta, będąca dla ludzi Zachodu symbolem zacofania, patriarchatu, ucisku i uprzedmiotowienia kobiet, w świecie muzułmańskim funkcjonuje jako znak kulturowej i religijnej tożsamości, a także - pomijając przypadki przymusu jej noszenia w krajach rządzonych przez muzulmańskich radykałów (np. w Iranie czy w Afganistanie) - kobiecej autonomii i wolności. W tym sensie inna okładka tego samego periodyku, przedstawiająca byłą premier RP Ewę Kopacz ubraną w afgańską burkę i trzymającą w ręku laski dynamitu (podpis pod zdjęciem: „Urządzi nam piekło na rozkaz Berlina”) wpisuje się w podobną islamofobiczną narrację, straszącą upadkiem Europy, islamizacją czy też „kalifatyzacją” kontynentu. W tak sterowanej prezentacji ostatnich wydarzeń znika świadomość, że wszystkie przemieszczenia ludności, te o charakterze uchodźczym, migracje ekonomiczne lub $\mathrm{w}$ poszukiwaniu lepszego miejsca do życia, są symptomatyczne dla modernizacji i globalizacji. $Z$ różnym nasileniem trwają właściwie od ostatecznego upadku zamorskich kolonii po II wojnie światowej. W perspektywie globalnej, ruchy migracyjne z krajów muzułmańskich do Europy stanowią tylko niewielki procent przemieszczeń [Castles, Miller 2011: 24-29], choć wydarzenia z ostatnich kilkunastu miesięcy gwałtowanie i radykalnie zmienily dotychczasowe statystyki i diagnozy.

Medialna kariera dramatycznej historii austriackich Boś/sz/niaczek, Samry i Sabiny, ujawniła zepchnięty dotąd na margines aspekt ambiwalentnego stosunku państw Europy Zachodniej do Bośni i Hercegowiny. Istnieją bowiem dwa równoprawne, choć skrajnie odmienne, wyobrażenia o Bośni i bośniackim islamie. Pierwsze, islamofilskie, pielęgnowane zresztą w charakterze pozytywnego autostereotypu przez samych Boszniaków, przedstawia ich jako tolerancyjne i nieortodoksyjne ofiary cudzej nienawiści. Tak postrzegani przez Europę Boszniacy to autochtoniczni europejscy muzułmanie, nieszkodliwi, niegroźni, którzy nigdy nie zwrócą się przeciwko jednej z dwóch „macierzystych” cywilizacji. Drugie, negatywnie nacechowane wyobrażenie, do niedawna reprodukowane głównie przez Serbów oraz w mniejszym stopniu przez Chorwatów, a ostatnio zauważalne coraz wyraźniej w krajach Europy Zachodniej, odwołuje się do zakorzenionego głęboko w bałkańskiej mentalności strachu przez islamem i islamizacją. Boszniacy jawią się w nim - to już serbska odsłona tej narracji - jako zdrajcy, „sprzedawczyki”, wyrachowani poturczeńcy, którzy dla własnych korzyści porzucili wiarę ojców [Aleksow 2000: 232]. Adam Balcer, związany z Ośrodkiem Studiów Wschodnich, przyczyn tego rozziewu w postrzeganiu Bośni przez Europę upatruje w przebiegu wojny po rozpadzie Jugosławii, choć ja byłabym skłonna dostrzec ich korzenie w czasach o wiele wcześniejszych, bo już w pierwszych dekadach osmańskiego podboju Bałkanów na przełomie XV i XVI w. [por. B. Jezernik]. „Podczas wojny sympatia zachodniej opinii publicznej wywołana cierpieniami muzułmańskich Bośniaków - najbardziej poszkodowanej strony konfliktu - sprawiły, że islamistyczne tendencje w Bośni i związki miejscowego islamu z radykalnymi środowiskami muzułmańskimi nie zostały odpowiednio 
nagłośnione” [Balcer 2003: 201]. W istocie, trudno odmówić Balcerowi racji, że wydarzenia takie jak masakra serbskiej ludności w Srebrenicy w lipcu 1995 r. (ponad 8000 ofiar) czy trwające przeszło dwa lata oblężenie Sarajewa (ponad 14000 ofiar) zagwarantowały Boszniakom współczucie zachodnioeuropejskich państw, z których najpierw kraje niemieckojęzyczne, a zaraz potem Skandynawia zdeklarowały się przyjąć bośniackich uchodźców. Zachodniej opinii publicznej istotnie umknęty takie fakty, jak przybycie do Bośni w latach 90. blisko trzech tysięcy arabskich, afgańskich, pakistańskich i syryjskich ochotników i muzulmańskich duchownych, chcących wesprzeć współwyznawców $\mathrm{w}$ walce $\mathrm{z}$ agresorem. Dla wielu z nich bośniacka misja wojskowa uformowanej w 1993 r. jednostki El-Mudżahid przerodziła się w misję religijną, jako że wyznawana przez Bośniaków wersja islamu wydawała im się za mało ortodoksyjna, zwłaszcza że sami w większości sympatyzowali z ruchem salafickim, potocznie nazywanym wahabizmem, który zresztą dziś w Bośni oraz z muzułmańskiej części Serbii ma swoich licznych wyznawców i sympatyków [por. Gil 2007: 197-224]. Obecność w Bośni mudżahedinów i doniesienia o obozach szkoleniowych finansowanych przez Al-Kaidę, zorganizowanych w małych, odciętych od świata bośniackich wioskach i miasteczkach (Žepče, Jablanica, Konjic), szybko stały się domeną wysokonakładowej, głównie serbskiej, prasy, co skutecznie odebrało temu tematowi należną powagę. Nierzetelnie przygotowane, utrzymane $\mathrm{w}$ sensacyjnym tonie reportaże i artykuły publikowane w tabloidach „Blic”, „Blesak” i „San” wywołały taki skutek, że nikt spoza kraju, kto zajmował się dziennikarsko lub naukowo wewnętrzną sytuacją Bośni, nie traktował ich poważnie. W 2006 r. ukazała się wprawdzie, wydana także w języku polskim, książka Jürgena Elsässera Jak dżihad przybyt do Europy. Wojownicy Boga i tajne stużby na Batkanach, jednak zachodniej opinii publicznej Bośnia jawiła się niemal wyłącznie jako pogrążający się w ekonomicznym kryzysie, niestabilny, zrujnowany przez wojnę kraj.

Analizowany tu przypadek Samry i Sabiny „otworzył puszkę Pandory” i zwrócił oczy europejskiej opinii publicznej na zapomnianą dotąd Bośnię i bośniackich imigrantów, mających swoje licznie skupiska w większości krajów europejskich. Bałkańskie media cytowały niemiecką prasę, przypisując jednej z dziewcząt słowa, że dzięki wyjazdowi do Syrii wreszcie czuje się wolna, mogąc praktykować swoją religię tak, jak dyktuje jej serce - w Wiedniu było to niemożliwe („Sabina kaže da je u kalifatu zadovoljna i da se ne želi vratiti kući, kao što se piše u zapadnim medijima. ,Ovdje mogu biti dosita slobodna. Mogu prakticirati svoju vjeru. U Beču to nisam mogla', rekla je Sabina)" [zob. http://dnevnik.hr]. Chorwacka, serbska i bośniacka prasa również podchwyciły ten wątek, a potem w kilkudniowych odstępach czasu informowały o kolejnych, analogicznych przypadkach. Przytoczmy tylko niektóre z nagłówków prasowych z ostatniego półrocza: „Bośniacka rodzina poszła na świętą wojnę” („Bosanska obitelj otišla u džihad, Jutarnji list“), „Werbował ich salafita z Maočy“ („Vrbovao ih je selafija iz Maoče, Dnevni avaz“), „Dżihadyści mają obozy w Bośni“ („Džihadisti imaju kampove u Bosni“). 
Także w samej Bośni zaczęto analizować kwestię, czy i ilu Bośniaków z kraju bądź z diaspory przyłączyło się do Państwa Islamskiego. Vlado Azanović, wykładowca na Wydziale Nauk Politycznych w Sarajewie i autor raportu pt. Zew wojny $w$ Syrii a bośniacko-hercegowiński kontyngent zagranicznych bojowników, przedstawił statystykę, zgodnie z którą 156 ochotników (mężczyzn i kobiet, w tym 25 nieletnich), pochodzących z Bośni i Hercegowiny lub mających bośniackie korzenie, w latach 2013-2015 przyłączyło w Syrii i Iraku do walk po stronie dżihadystów. Azanović odtworzył też kanal, jakim Bośniacy przedostają się do Syrii z Sarajewa przez Turcję, do miast Kilis i Azaz. Azanović nie zdołał ustalić jednego modelu radykalizacji ideologicznej, poprzedzającej decyzję o wstąpieniu w szeregi bojowników Nowego Kalifatu, zwrócił jednak uwagą na ważną kwestię działań tzw. „wędrownych autorytetów” - charyzmatycznych nauczycieli, duchownych, weteranów, którzy w zagranicznych skupiskach diaspory zajmują się werbowaniem młodych, rozczarowanych i zagubionych ludzi:

Istraživanjem nije bilo moguće utvrditi postojanje jednog, po karakteristikama i trajanju, tipičnog ili dominantnog oblika ideološke radikalizacije koja prethodi odlasku na ratišta u Siriji/Iraku. Na temelju uvida u otvorene i dio povjerljivih izvora moguće je zaključiti da proces radikalizacije provode ili nadgledaju lokalni ili „putujući autoriteti”, te da su odlascima u Siriju, u nekim slu- čajevima, prethodile ubrzane radikalizacije, uglavnom mlađih, otuđenih i često dezorijentiranih osoba, moguće s narušenim mentalnim zdravljem. [Azanović 2015: 49]

\section{Zakończenie}

O zjawisku polaryzacji nastrojów i tendencji w Bośni i Hercegowinie, tj. o radykalizującym się islamie bośniackim z jednej strony oraz postępującej laicyzacji z drugiej, pisałam już kilka lat temu, w opublikowanej w 2014 r. książce Boszniacy. Literackie narracje tożsamościowe po 1992 roku. Sformułowałam takie wnioski jeszcze zanim Europa stanęła przed potężnym kryzysem i wyzwaniem, spowodowanym wydarzeniami ostatnich kilku miesięcy. Obserwując życie polityczno-społeczne w Bośni, czytając tamtejszą literaturę i prasę postawiłam diagnozę, że „W niedalekiej przyszłości będzie dokonywać się dalsza radykalizacja bośniackiego islamu”. W parze $\mathrm{z}$ boszniacką tożsamością męczennika za wiarę $\mathrm{w}$ duchu islamskiej idei szahadatu idzie bowiem reislamizacja bośniackiej kultury i życia codziennego. Jej przejawy, takie jak próby wprowadzenia zakazu sprzedaży i spożywania alkoholu w historycznym centrum Sarajewa, obecność ortodoksyjnych nurtów islamskich (wahabizm), stale rosnący odsetek kobiet decydujących się na zakrycie twarzy (w skrajnych przypadkach nawet całego ciała, hidżabem lub nikabem), są coraz bardziej zauważalne. Kwestią czasu było więc pojawienie się analogicznych tendencji na emigracji, co nie powinno dziwić, jeśli weźmie się pod uwagę liczne kontakty przedstawicieli boszniackiej diaspory, choćby w me- 
czetach lub wielonarodowych imigracyjnych dzielnicach, z przedstawicielami innych, pozaeuropejskich muzułmańskich narodów. Taką konstatację należy traktować bardzo ostrożnie, przy zachowaniu właściwych proporcji. Nawet, jeśli doniesienia o obecności Bośniaków w szeregach bojowników Państwa Islamskiego są prawdziwe, należy mieć świadomość, że mówimy zaledwie o niespełna dwustu osobach. Na tle czteromilionowej populacji kraju i blisko dwumilionowej społeczności na emigracji to wciąż bardzo niewiele. Nie da się zaprzeczyć, że w niektórych środowiskach wewnątrz $\mathrm{BiH}$ oraz serbskiego Sandżaku dochodzi do radykalizacji postaw religijnych, trzeba mieć jednak na uwadze, że takie zjawiska nie są zawieszone w próżni, mają natomiast silne uwarunkowania ekonomicznie, społecznie oraz geopolitycznie i, jak dotąd, stanowią jedynie margines i promil wszystkich postaw. $\mathrm{Z}$ przedstawionej tu perspektywy nasuwa się wniosek, że może nawet bardziej niebezpieczny jest islamofobiczny dyskurs opanowujący Europę, skutkujący pogłębiającymi się podziałami społecznymi, niezrozumieniem i rosnącą nieufnością. Zwrócenie uwagi opinii publicznej (także w Polsce) na bośniacką diasporę, w kontekście kryzysu imigracyjnego, jest tego najlepszym przykładem.

\section{LITERATURA}

[Aleksow 2000] - B. Aleksów, Poturica gori od Turčina, za: postjugo.uj.edu.pl, Kraków.

[Azanović 2015] - V. Azanović, Zov rata u Siriji i bosanskohercegovački kontingent stranih boraca, Atlanstska inicijativa, Sarajevo.

[Balcer 2003] - A. Balcer, Polityczny islam w Bośni oraz jego związki z Bliskim Wschodem i muzutmańskim terroryzmem, [w: Islam a terroryzm, red. A. Parzymies, Wydawnictwo Akademickie Dialog, Warszawa.

[Castles, Miller 2011] - S. Castles, M. J. Miller, Migracje we współczesnym świecie, Wydawnictwo Naukowe PWN, Warszawa.

[Dervišević 2006] - A. Dervišević, Bošnjaci u dijaspori. Historijat, problemi, analize i perspektive, knj. 1, Bosanska riječ, Sarajevo.

[Gil 2007] - D. Gil, Serbscy Boszniacy (Bošnjaci). Pomiędzy fundamentalizmem a dialogiem międzyreligijnym prawosławnych i muzutmanów w Sandžaku, [w:] Prace Komisji Kultury Stowian PAU, red. L.Suchanek, t. VI: Stowianie i ich konfesje, Kraków.

[Hanne, de La Neuville 2015] - O. Hanne, T. Flichy de La Neuville, Państwo Islamskie. Geneza nowego kalifatu, Wydawnictwo Akademickie Dialog, Warszawa.

[Jawoszek 2014] - A. Jawoszek, Boszniacy. Literackie narracje tożsamościowe, Nauka i Innowacje, Poznań.

[Jezernik 2010] - Imaginirani Turčin, Biblioteka XX vek, Beograd.

[Karić 2012] - A. Karić, Položaj muslimana u Evropskoj uniji. Velika Britanija, Njemačka $i$ Švedska, Dobra knjiga, Sarajevo.

[Rusinek 2012] - A. Rusinek, Nurt radykalny wśród społeczności muzutmańskich w wybranych państwach Unii Europejskiej, Wydawnictwo Uniwersytetu Warszawskiego, Warszawa. 
[Said 2005] - E. Said, Orientalizm, Wydawnictwo Zysk i S-ka, Poznań.

[Smajlović 2012] - S. Smajlović, S Bošnjacima diljem svijeta, El-Kalem, Sarajevo.

[Young 2012] - R. J. C. Young, Postkolonializm. Wprowadzenie, Wydawnictwo Uniwersytetu Jagiellońskiego, Kraków.

\section{Strony internetowe}

Avaz.ba

Blic.rs

Dnevnik.hr

Jutarnji.hr

Ndie.pl

Oslobodjenje.ba

Radiosarajevo.ba

Telegraf.rs

Tvp.info.pl

Agata Jawoszek

\section{BOSNIAK DIASPORA IN WESTERN EUROPE IN THE LIGHT OF THE IMMIGRATION CRISIS AND THE GROWING ISLAMOPHOBIA MEDIA, IDENTITY AND POLITICS}

\section{(Summary)}

The Immigration crisis and thousands of refugees arriving to Europe in a search for a better, more dignified life, and the constantly growing concern caused by the terrorists from ISIS contribute to islamophobic sentiment in Europe. Bosniaks, or Bosnian Muslims, are the largest diaspora from the former Yugoslavia in Western Europe. It is estimated that out of Bosnia and Herzegovina there is more than 3 million Bosniaks and people from Bosnia. First of all, we can speak about war refugees, who left their homeland between 1989 and 1995 (during the war after the fall of Yugoslavia) and about representatives of the earlier economic and political emigration from Yugoslavia (so called gastarbaiters). Nowadays, anti-Muslim sentiment in Europe on the one hand, and the growing radicalization of Muslim immigrant communities in European main cities, the involvement of various immigrant communities in the Syrian conflict and the activities of the Islamic State, have an influence on the life of Bosniaks living abroad. In my paper I present the results of my research on immigrant Bosniak communities in Ljubljana, Vienna, Berlin and Oslo. I analyze their political and cultural activities as a their reaction to recent events such as the Paris attacks in November 2015. 